\title{
Participation: Some Basic Considerations on the Theme Of Academe
}

In this article three questions are asked: (1) whether faculty status for librarians automatically leads to greater participation in management; (2) whether the academic department is the best model for librarians; and (3) whether lack of skill in introducing participation may not lead to disillusionment. Studies are cited showing that faculty participation in the governance of higher education is being eroded, and examples are given of currently-discussed models of governance.

\section{INTRODUCTION}

W HAT ARE THE EXPECTED ADVANTAGES of staff participation in the making of management decisions? According to some librarians, we can expect an acceleration in the professionalization of librarianship, improved morale, an increase in innovative ideas, and better service to library users. ${ }^{1}$ On the other hand, because participation is new to many librarians, we do not know whether these favorable developments will necessarily ensue. Although for some observers, faculty status for librarians leads naturally to greater and significant participation in the making of academic-management decisions, our evidence indicates that the granting of faculty status will not necessarily bring about significant participation.

The Association of College and Research Libraries has recommended faculty status for librarians, and the reorganization of libraries as teaching units, with deans and departmental chairmen.

Mr. Kaplan is professor at the University of Wisconsin Library School, Madison.
Before accepting this model for libraries we should note that professors are themselves disturbed by the "managerial" revolution in higher education, which has resulted in a new tier of officials standing between faculty and those who make administrative decisions of importance to higher education. As a result, new models of academic organization are being discussed.

Some librarians believe that faculty status and participation will transform them into "free spirits," unburdened by work schedules and other hierarchical inconveniences. However, recent evidence indicates that professors do not claim freedom from review in such matters as teaching hours, tenure, and the initiation of new courses. Judging from studies of participation made in nonlibrary organizations, much disappointment will be experienced with participation, largely because of lack of skill and unreal expectations. In time, many claims will be made on behalf of participation; but, as one keen student of participation has said, these claims will be difficult either to prove or to disprove. 


\section{THE Model of THE Teaching Department}

Bundy, seeking ways to reduce conflict in libraries (especially between professionals and nonprofessionals), recommends the granting of faculty status to librarians and the reorganization of libraries on the model of higher education. Using this model, Bundy would create the equivalent of academic vicepresidents in charge of the humanities, the social sciences, and the natural sciences; within each division, departments "would be run on the relatively democratic basis of teaching departments in a university, where regardless of rank, every faculty member has an equal voice and an equal vote."

Like Kaser (see reference 22), Bundy does not consider the relationships of departments within a college, nor their dealings with their dean. Yet, as any professor knows (including Kaser and Bundy), it is the "foreign affairs" of departments that are no less crucial than the internal. Among these are budgetary decisions (subject to the review of deans) and promotions to tenure (much influenced by colleagues in other departments and by deans).

Those who neglect the "foreign affairs" of departments miss the import of what Rourke has called the "managerial revolution." As Rourke points out: "The most paradoxical development in higher education in recent years has been the fact that the status of the individual faculty member has been growing on university campuses, even while his participation in university government has been declining." 3 Several reasons are cited by Rourke for this development: the race for research support has diverted attention from the problems of administration; complications have resulted from the spectacular growth in enrollments; the introduction of systems analysis and operations research has brought to the campus a new level of administrative officers who stand between the faculty and the toplevel administrators. As a result of these factors, says Rourke, management becomes a major growth industry in higher education. ${ }^{4}$

As has been widely noted, student uprisings have brought a decline in university support, and with this has come the conviction that universities have undertaken contradictory tasks. As one observer put it, the university is being charged with the failure to "fashion a structure appropriate to its purpose." Thus the university and its faculty are threatened with a decline in autonomy, one sign of which is the introduction of bills in state legislatures to end tenure. In this situation, deans and presidents who believe that departments blindly resist change will be encouraged to move against these departments with greater determination.

\section{Who Administers Departments?}

The author of one study found that of sixty-nine departments (in fifteen universities), thirty-four rated themselves as a combination of bureaucratic and democratic, sixteen were said to be oligarchic, sixteen were seen as a combination of autocratic and paternalistic, while only three rated themselves as laissez-faire. ${ }^{6}$ In these fifteen universities the chairmen are "like foremen, men in the middle, who are besieged by both management and workers to represent and promote the divergent interests of both parties." In departments heavily dependent upon university funds, the faculty seeks to appoint a chairman who is articulate and of attractive personality to deal with the dean. The "departmental chairman who had the confidence of both his faculty and central administration was virtually guaranteed as long a tenure in office as he wished."8 Presumably, because departments in libraries depend heavily or exclusively 
upon funds obtained through their directors (deans), it will become apparent to librarians as they learn to play the academic political game that a strong chairman can be preferable to a democratic chairman who has little influence with the dean.

Asked to indicate the sources of departmental problems, 50 percent identified the source to be "external to or beyond the control of the departments." As to how to resolve these problems, 27 percent felt that the solution required the removal entirely of external influence, while 25 percent believed that more money would alleviate their problems. ${ }^{9}$

\section{Strong Deans \\ and Prestigious Departments}

As Caplow has shown, professors are expected to teach, but the reason for employing a professor is his research potential and his presumed ability to attract other scholars to his department. ${ }^{10}$ Prestigious departments are those in which research is being published, and it is these that have the greatest influence with their dean.

Departments, like individuals, are largely "local" or "cosmopolitan" in outlook. Those with a local orientation stress public service and undergraduate teaching. The cosmopolitan are oriented towards making a national reputation, and are more research-minded. In institutions in which research is stressed, it is the cosmopolitan departments which take the lead in the search for funds in support of research and teaching. The more money a department can find on the outside, the less its dependence for funds upon the dean.

In departments where the dean is perceived as "strong" (that is, the dean is known to stand up to departmental demands), there is a tendency on the part of departmental chairmen not to delegate decision-making. ${ }^{11}$ Furthermore, chairmen are more likely to share deci- sion-making in departments of prestige. ${ }^{12}$ Prestigious departments believed the source of their problems to be largely external, whereas in nonprestigious departments the source of their problems was most often perceived to be internal. ${ }^{13}$

\section{Colleges Compared WITH UNIVERSITIES}

In a recent study of eleven private, liberal arts colleges in the Midwest, all of good academic quality, McGee found that the most important aspect of department prestige was its personnel, and these, as in universities, were judged mostly by their publications. "In assessing others, men tend to use scholarly productivity as an almost exclusive criterion." 14 Though college teaching as a career is open to persons without the doctorate, those without the degree "may expect to be second-class citizens of academia."15

Those whose image of the college is one in which the faculty have considerable autonomy must indeed be surprised by McGee's observation that "the majority of the campuses I visited for this study were still administered more or less on what could be called the Nineteenth Century Autocratic Model." Though some had active faculty organizations, "it is relatively rare in the colleges surveyed for faculty actually to be involved in administrative decision making. . . ." Too many deans, wrote McGee, "play it close to the vest when dealing with their faculty members."16

\section{Two General Rules}

To summarize, even in well-regarded universities and colleges, faculty perceive themselves members of a hierarchy. True, the hierarchy, insofar as it impinges upon them is less bureaucratic than is the hierarchy in other organizations. Still, the hierarchy is there and is all the more noticeable because (as Corson noted in a study undertaken 
for the Carnegie Corporation) the lines in the academic hierarchy are mixed. The one is more or less a straight-line relationship from president through various officers, and down to the departmental chairmen. "The other is formed by the various faculty legislative bodies primarily concerned with educational policy and emanating from the faculties of individual departments upward to institution-wide councils or a 'senate' or meetings of the total faculty." 17

In addition to the inevitability of its hierarchical element, two general rules govern the administration of higher education. First, chairmen and deans tend to follow the pattern of the institution as a whole. Where trustees and president are disdainful of faculty opinion, deans and departmental chairmen are likely to follow. If this pattern holds true for libraries (as it generally appears to do), chairmen of library departments and library deans likewise will be influenced by the type of institution in which they serve. Second, the less prestigious a school, the more likely will the trustees, president, and deans interfere in departmental affairs. In many schools (which do not deserve to be classed among institutions of higher learning), the professor is regarded as an interchangeable part.

\section{The Search For New \\ ACademic Models of Governance}

It will come as a surprise to some librarians who are unfamiliar with departmental procedures to learn that professors do not claim absolute autonomy -even in matters relating to education proper. On this point we have the results of a study of faculty in forty-two (mainly) large public universities. ${ }^{18}$ Of the 10,000 faculty who received questionnaires, 40 percent responded (but responses from the "elite" universities were relatively few). The object of this study was to learn, with respect to actions initiated in departments, at what level the faculty believed review of these actions to be reasonable.

Among the departmental actions which the faculty believed ought not to be reviewed at a higher level were changes in an existing course, and course requirements. Among the departmental matters which were properly reviewed at the college level were faculty salaries, time of class meetings, number of contact hours with students, the selection of departmental chairmen, promotion to tenure, and reduction in teaching hours in exchange for research.

If these opinions reflect existing conditions, it follows that librarians enjoying faculty status in a library organized on the academic model cannot expect significantly to determine the conditions of their employment except after review by others. In some matters, however, the autonomy of the librarian is comparable to that of the classroom professor, as for example, with reference librarians who are not given a set of rules by which to proceed.

Given the belief of some faculty members that the control of educational matters has tilted in the direction of administrators, professors have cast about for a new model of academic governance. Among these is Demerath who has described what he calls the Neo-Scientific model in which there is a marriage of the hierarchical and the collegial. Employees in the hierarchical would concern themselves with business affairs, while those in the collegial, freed of the hierarchical element, could devote themselves exclusively to "goal setting and policy-making for teaching, research and service."19 Although resembling the model proposed by Bundy (noted earlier), the difference is that the teaching faculty might want, as Rourke suggested, to create a civil service specially trained to serve its needs, whereas librarians already have at hand a corps of nonprofessionals. ${ }^{20}$ The weakness of the model is that nonpro- 
fessionals can be expected to demand the right to share in decision-making. Another model seems to be developing in some German universities, called the political. ${ }^{21}$ Unlike Bundy's model, all strata of employees are included, that is, all are given the privilege of voting for representatives. In libraries, this would mean that nonprofessionals, including student assistants, would be represented in some proportion to their numbers (or by some other method of apportionment). If the American political model were employed, it would include a chief of state (the head librarian) with an executive staff, working alongside the legislative arm of the government. Presumably, the chief would have the power of veto, which the legislative branch (by a vote greater than a simple majority) could overturn.

The political model calls for compromise solutions; the traditional consensus model, however, would separate policy making from policy implementation. Kaser has related this consensus concept to libraries in what he refers to as a "bipartite" structure. By this he means that for policy making the professionals in a library would act as an assembly, but once the policy is determined its implementation would become the task of the hierarchical structure. A department chief, for example, would convene an assembly of peers, during which he would act in the capacity of chairman; policy implementation would then be taken over by the chairman, acting in his capacity as a department chief. ${ }^{22}$

More discouraging to those who abhor the hierarchical structure, is the argument of Barbash who denies the possibility of escape from the hierarchical. ${ }^{23}$ According to him, certain conditions lead inexorably to hierarchies in organizations, these being, among others, their size, the multiplicity of skills required, the need to consider cost, and regulatory activities of the state. Once organization is created, the hierarchy follows. On the other hand, Barbash believes that whereas tensions are inescapable in the organization, ameliorating tactics are possible-even though these too create further tension. What counts is whether or not the ameliorating factors -such as unionism and participation in management decisions-are strong enough to overcome the tendency of hierarchical organizations to develop bureaucratic characteristics. Barbash believes that hierarchies create conflict because of the resentment of subordinates toward superiors. If hierarchies are to continue in libraries, this resentment is no doubt one of the chief problems to which participation must address itself.

\section{The Cructal Issues}

The natural inclination in introducing participation is to organize a series of committees. This is the traditional approach in a democratic nation and in its academic institutions. Although committee membership is attractive to those who have felt the heavy hand of autocracy, the overwhelming attitude of professors toward committee work is one of distaste: it seems that the more a professor complains about administrators, the more he resents being asked to serve on committees. Furthermore, as "participatory democracy" has been offered as an alternative to our representative form of government which is committee oriented (in one sense, our legislatures are a kind of committee), the disenchanted librarians of the future might make a similar attack on participation through committees. They might argue that each "enclave" in the library should make its own decisions based on total representation of its members.

There are two kinds of committee structures. One is "problem" oriented, and leads to the appointment of committees on professional development, the employment of minorities, staff orientation, and the like. By way of contrast there is the route taken by UCLA, 
in which the committee structure is largely grafted upon organizational lines; that is, each separate library and each of the several departments within the general library have their committees, which in turn, elect representatives to a library-wide committee. Additionally, there are a number of staff resource committees (such as for personnel, collection building, facilities and supplies, and communications).${ }^{24}$

A problem with this organizational model is that changes in the organization may be resisted by those who fear a diminution of their status in the representational pattern; for example, two departments when combined might insist upon their previous number of representatives. With the problem-oriented committees there is constantly the danger that they will continue long after the need for them is past; even those who are bored are reluctant to recommend the termination of their assignment. Presumably, a committee on committees, if it has the wisdom and the courage, will attend to the committee that requires burial.

Aside from these considerations, a crucial issue (assuming all are genuinely interested in giving participation a trial) is the skill required at the introductory stages; the mere spelling out of a governance document is not enough. Judging from Holley's evaluation, librarians are finding it difficult to come to grips with the role of policy making. ${ }^{25}$ If participants in decision-making only discuss vacation schedules and Christmas parties, the considerable claims made for participation will fall. Morale may be somewhat improved, but as students of organizations know, those with high morale are not necessarily loyal to the goals of the organization. If innovation is to surpass the petty concerns of bureaucracies, a useful first step might be participation in goal setting. The merits of this approach are that those who participate in goal set- ting are more likely to approve of the goals and are more willing to work to achieve them; and that in the process of setting goals, persons unfamiliar with the library as a whole and its place within the university, will gain valuable insights.

One technique used in goal setting is to ask the participants to indicate the present goals of the library and the goals that ought to be established. Gross, for example, recognizes five main goals: output; adaption (such as adapting services to the needs of special groups); management; motivational (goals that are likely to promote loyalty to the institution); and positional (such as those designed to gain prestige for the library). ${ }^{26}$

\section{Conclusion}

Participation, while difficult to initiate and sustain, can no longer be safely avoided. As Katz has pointed out, there is a conflict between democratic expectation and the ability and opportunity to share in the decisions that affect an individual's role in his organization. ${ }^{27}$ Particularly in large organizations, the centers of decision-making tend to be removed from the persons most affected, and as these persons become discouraged they resort to blind conformity or to blind opposition.

Some librarians are perhaps unaware that participation is not new to library history. In an earlier day participation was known as democracy in administration, and articles by its advocates began to appear with some regularity after $1930 .{ }^{28}$ What is different today is the greater number who wish to participate, and the expectation that the channels of participation will be institutionalized.

Lowin, a student of participation, reminds us that the benefits of participation are subject neither to absolute proof nor disproof, and that no complex organization can ever operate purely on the participatory principle. ${ }^{29}$ 
Judging from the literature which Lowin cites on participation in nonlibrary organizations, for years to come library journals will carry articles prov- ing the benefits of participation, or the reverse. Although some will remain unchallenged, others will become the subject of considerable controversy.

\section{REFERENCES}

1. See, for example, Mary Lee Bundy, "Conflict in Libraries," CRL 27:253-62 (July 1966); Edwin Castagna, "Democratic Administration," Library Journal 82:3138-44 (15 Dec. 1957); Maurice P. Marchant, "Participative Management in Libraries," New Directions in Staff Development, ed. by Elizabeth W. Stone (Chicago: ALA, 1971) p.28-36; and B. Fouche, Professionalisation and Bureaucratisation (Pretoria, Mousaion, 1972).

2. Bundy, "Conflict."

3. Francis E. Rourke, The Managerial Revolution in Higher Education (Baltimore: Johns Hopkins, 1966) p.128.

4. Ibid., p.5-15.

5. Daniel Bell, "Quo Warranto?-Notes on the Governance of Universities in the 1970's," The Embattled University, ed. by Stephen R. Graubard (New York: Braziller, 1970) p.223.

6. The most prestigious universities were not included in this study, but the academic credentials of those surveyed are not to be belittled. Among them were the University of North Carolina, Northwestern, Pennsylvania State, and the University of Southern California. Paul L. Dressel, The Confidence Crisis (San Francisco: Jossey-Bass, 1970) p.41-42.

7. Ibid., p. 81-82.

8. Ibid., p.140-41.

9. Ibid., p.94-96.

10. Theodore Caplow, The Academic Marketplace (New York: Basic Books, 1958) p. $82,108$.

11. Dressel, Confidence Crisis, p.61-63.

12. Ibid., p.83-84.

13. Ibid., p.105.

14. Reece McGee, Academic Janus (San Francisco: Jossey-Bass, 1971) p.166-72.

15. Ibid., p.97.

16. Ibid., p.208-9.

17. John J. Corson, Governance of Colleges and Universities (New York: McGraw-Hill, 1960) p.35.
18. Paul L. Dressel, Return to Responsibility (San Francisco: Jossey-Bass, 1972) p.3435.

19. Nicholas J. Demerath, Power, Presidents and Professors (New York: Basic Books, 1967) p.216-17.

20. Rourke, The Managerial Revolution, p. 129.

21. See the chapter on German universities in Christopher Driver, The Exploding University (Indianapolis: Bobbs-Merrill, 1971) p. 194-202.

22. David Kaser, "Modernizing the University Library Structure," CRL 31:227-31 (July 1970).

23. Jack Barbash, "The Tensions of Work," Dissent, p. 240-48 (Winter 1972).

24. This brief description is based on an organization chart and a statement in manuscript by Johanna E. Tallman, "The New Library Management Network at the University of California, Los Angeles," revised June 27, 1969. I am indebted to Robert Vosper for this material.

25. See a brief discussion of these in Edward Holley, "Library Governance in Higher Education: What Is Evolving?" Minutes of the 80th Meeting of the Association of Research Libraries, p.31-32 (May 1972).

26. Edward Gross, "Universities as Organizations: A Study of Goals," Academic Governance, ed. by J. Victor Baldridge (Berkeley: McCutchan, 1971) p.22-57. The original essay appeared in the American Sociological Review 33:518-44 (Aug. 1968).

27. Daniel Katz, The Social Psychology of Organizations (New York: John Wiley, 1966) p.470.

28. For a review of the early literature see Amy Winslow, "Supervision and Morale," Library Trends 3:39-51 (July 1954).

29. Aaron Lowin, "Participation Decision Making," Organizational Behavior and Human Performance 3:68-106 (Feb. 1968). 